\title{
Postcolonial Powers of Opposition in Octavia Butler's Kindred
}

\author{
Thamer Amer JubouriAl_Ogaili \\ Faculty of Modern Languages and Communication, Universiti Putra Malaysia, Malaysia \\ Ruzbeh Babaee (Corresponding author) \\ Faculty of Modern Languages and Communication, Universiti Putra Malaysia, Malaysia \\ E-mail: ruzbeh_babaei@upm.ed.my
}

Received: 16-09-2015

Published: 01-03-2016
Accepted: 17-12-2015

doi:10.7575/aiac.ijalel.v.5n.2p.137
Advance Access Published: January 2016

URL: http://dx.doi.org/10.7575/aiac.ijalel.v.5n.2p.137

\begin{abstract}
This study will examine postcolonial powers of opposition in Octavia Butler's Kindred (1979); through Homi Bhabha's concept of ambivalence and Edward Said's self-other relationship. By using these concepts, this research aims to unravel how the colonized and the colonizer perceive each in the selected works. It will offer an in-depth analysis of the thematic and ideological characteristics of selected works. Thus, the focus will mainly be on the theme of the mutual relationship between the colonized and the colonizer in the selected works. This relationship is specified to the concept of ambivalence. This concept incarnates the dual, yet, uncontrolled relationship between the colonized and the colonizer. Nevertheless, the colonized considers the colonizer as oppressive but an envious power; and the colonizer judges the colonized as inferior but indigenous. The colonial relationship will also be revealed by using the concept of self-other. Such concept scrutinizes the way the colonized and the colonizer perceive and resist each other. Accordingly, the research's main focus point is the power relationship developed in the light of colonial ambivalence and self-other continuum. The research's methodology relies on Bhabha's concept of ambivalence and Edward Said's self-other relationship. In The Location of Culture (1994), Bhabha maintains that the concept of ambivalence conveys "the exercise of colonialist authority, however, requires the production of differentiations, individuations, identity effects through which discriminatory practices can map out subject populations that are tarred with the visible and transparent mark of power" (111). Edward Said, in his discussion of self-other relationship in Orientalism (1979), argues that selfother relationship is "the vacillation [inconstancy] between the familiar [self] and the alien [other]" (72).
\end{abstract}

Keywords: Ambivalence, Butler, Hegemony, Postcolonialism, Self-Other Relationship

\section{Introduction}

Octavia Butler is an African American writer who exposes the inherent relationship between the white and the black. What so distinctive about her fiction is the colonial quality which is set in historical peripheries critiquing and dealing with the earliest encounter between the whites and the blacks. The core conceptual discrepancy in her fiction, moreover, is her science fiction literary peculiarity. This literary mode renders her a distinctive place among the African American writers who deal with crucial themes in the history of black migration to America. Additionally, Butler presents a resistance voice for the suppressed colonized voices and identities to affirm their human existence. Since the dawn of the African migration to the New World, there had been a sense of racial discrimination on the basis of color, identity, social class, and gender. The real impetus behind such discrimination is the whites' reclamation of their identity as the owner of the New World. This racial practice was handed down through decades during which the blacks could not affirm or gain certain human identity. Accordingly, literary fiction arose and gave a meager voice for the suppressed blacks to obtain a subjective identity paving the way for their rights as equal to their white counterparts. Being a black writer, Butler used her fiction as a means of exposing that reality; the reality of black and white racial discrimination (Loomba 36). In fact, through his fiction, Butler represents "critical stances upon contemporary colonial matters and the degenerating oppressive powers" (Ogaili \& Babaee 166).

The purpose of this paper, therefore, is to study the colonial encounter between the blacks and the whites in Butler's Kindred. The main focus will be on the self other relationship. This relationship involves both the blacks and the whites; and they are analyzed as the "self" or the "other" in the light of Edward Said's concept of self-other relationship. This relationship will be elaborated by applying the concept of hegemony. The concept of hegemony unravels the white's colonial supremacy over the blacks. Homi Bhabha's concept of ambivalence, furthermore, will be applied to identify how the blacks and the whites perceive and judge each other.

\section{Self-Other Relationship}

Butler's Kindred is a fictional narrative exposing the black experience in colonial periods. The novel is recounted in different consecutive episodes; a Prologue, The River, The Fire, The Fall, The Fight, The Storm, The Rope, and an 
Epilogue, respectively. In essence, the novel narrates the internal dilemmas of racism in the America history. Dana, who is the main character, is a female protagonist exemplifying the sense of racial themes, such as the authentic portrayal of slavery and slave societies. She also incarnates the colonial encounter between master and slave relationship; whereby the master practices hegemonic supremacy over the slave. The novel proportionately has a conspicuous critique of the American colonial history, as well as Racism and social classes. Other than Dana; there are several characters, among them are Rufus Weylin, Kevin Franklin, Tom Weylin, Alice Greenwood and others who represent the self-other relationship between the blacks and the whites.

In Kindred, the self-other relationship when the narrator begins the story of police who arrested Kevin and set him free after that: "And I lost about a year of my life and much of the comfort and security I had not valued until it was gone. When the police released Kevin, he came to the hospital and stayed with me so that I would know I hadn't lost him too" (9). Kevin's arrest is an incarnation of the beginning of racial discrimination between the blacks and the whites because he is not free as ever: "he could come to me, I had to convince the police that he did not belong in jail. That took time. The police were shadows who appeared intermittently at my bedside to ask me questions I had to struggle to understand" (9).

To argue this point, the postcolonial discourse posits the notion of racial discrimination in the self-other relationship. Edward Said, in Orientalism (1978), argues that racial discrimination comes out of "power, of domination, of varying degree of a complex hegemony" (5). Additionally, racial discrimination "is not innocent but profoundly connected with the operations of power' (italics in original)" (p43). Said asserts that the "colonizer knowledge of the colonized goes arm in arm with expansionism, exploration and settlement" (8). This is the measurement of self-other relationship which involves "the conventional axis of interaction between the colonizer and colonized or the self and the Other" (42). In this manner, the colonized and the colonizers relationship "must create its own other; because of this other it can strengthen its own identity and superiority and because of this other it can set off against the Orient as " a sort of surrogate and even underground self" (3).

In the light of Said argument, the self-other relationship arises in terms of affirming the identity during trouble and hard times. This is true to Kindred where troubles begin between the blacks and the whites in the first phases of their colonial encounter: "The trouble began long before June 9, 1976, when I became aware of it, but June 9 is the day I remember. It was my twenty-sixth birthday. It was also the day I met Rufus - the day he called me to him for the first time" (12). Furthermore, Kevin and the narrator tell these events describing their negative effects: "Kevin and I had not planned to do anything to celebrate my birthday. We were both too tired for that. On the day before, we had moved from our apartment in Los Angeles to a house of our own a few miles away in Altadena" (12). Kevin and the narrator seem to be upset by such drastic events: "The moving was celebration enough for me. We were still unpacking - or rather, I was still unpacking. Kevin had stopped when he got his office in order. Now he was closeted there either loafing or thinking because I didn't hear his typewriter. Finally, he came out to the living room where I was sorting books into one of the big bookcases. Fiction only. We had so many books, we had to try to keep them in some kind of order" (12).

Kevin and the narrator represent the colonial insights in the novel. They are the essence of the self-other relationship because this relationship is "a process which incorporates identifying oneself and being recognised by others. Identity is, therefore, seen here as embedded in social relations and as dynamic, contextual and relational. Social representations and the dynamics of positioning between self and other define identities" (Moscovici 107). It also includes the "social representations "which"is based on a "systematic social psychology" (107). The social factors are essential to the selfother relationship because "the relationship between the self and the other is mediated through the intervention of another subject; this relationship becomes a complex triangular one in which each of the terms is fully determined by the other two" (107). Therefore, the cultural identity originates in this social circumstance.

This social dimension appears in Kindred. The narrator wonders how Kevin changed by the colonial practices of the whites: "He gave me a look that I knew wasn't as malevolent as it seemed. He had the kind of pale, almost colorless eyes that made him seem distant and angry whether he was or not. He used them to intimidate people (13). The narrator also describes himself and the other as strangers in their land: "Strangers. I grinned at him and went back to work. After a moment, he took the nonfiction to another bookcase and began shelving it. I bent to push him another box full, then straightened quickly as I began to feel dizzy, nauseated. The room seemed to blur and darken around me" (13). Being strangers, the narrator and his other compatriots could not affirm their right to gain their land: "I stayed on my feet for a moment holding on to a bookcase and wondering what was wrong, then finally, I collapsed to my knees. I heard Kevin make a wordless sound of surprise, heard him ask, 'What happened?"' (13). So the narrator's compatriots identity is stolen.

In postcolonialism, the study of identity is inseparable of the study of the self-other relationship. This is because "the question about identity without posing the question about self and other. And one cannot talk about social representations as a theory of social knowledge without examining public discourses in which different dialogues between the self and the other take place and through which they generate representations" (Marková219). Additionally, this relationship "has incorporated the self-other-object triangle in his theorisation of identity. The main proposition is that social representations provide various possible identities which allow people to position themselves in a variety of ways in relation to the symbolic field of culture (Duveen171). Being that so, the self-other relationship and "these identities, taken on and negotiated by individuals, help them structure their social world and orient themselves within this world" (171). 
This relationship is conspicuous in Kindred, especially in Rufus's character. Rufus wants to regain his and his parents identity: :Rufus and his parents had still not quite settled back and become the 'dream' Kevin wanted them to be. They stayed with me, shadowy and threatening. They made their own limbo and held me in it" (18). He wants to be free of any fear threatening him: "I had been afraid that the dizziness might come back while I was in the shower, afraid that I would fall and crack my skull against the tile or that I would go back to that river, wherever it was, and find myself standing naked among strangers. Or would I appear somewhere else naked and totally vulnerable? (18).

Being free of any threat is a token of the self-other discrepancy. Such discrepancy has "principally examined the mediation of social representations of gender in communication processes and their impact on knowledge construction. The results of these studies demonstrate that recognition can be hindered or facilitated by the social representations of gender" (Psaltis 209). It is also "the social representations of self position as more knowledgeable than the other. In other words, the knowledge produced by self is perceived as more 'valid' than the knowledge produced by the other. People 'act through' these social representations and therefore, these representations shape the interactions between people" (209). Here, this knowledge "has an impact on knowledge construction because different self-other relations correspond to different communication types which give rise to different kinds of knowledge construction processes" (209). Therefore, it is "the quality of self-other relations that shapes knowledge construction. From this perspective, identity and (mis-)recognition are crucial in social representation processes" (209). These social representations "provide people with a variety of positions but these positions are further elaborated by one's relations with an 'other"" (209).

The self's knowledge is more important than the other's knowledge in Kindred. This is evident in the blacks' knowledge of their land's territories and their psyche. They know them more than the whites: "I stared out into the darkness fighting to calm myself. It was not calming, though, that there were no city lights out there. No lights at all. But still, I was in no immediate danger. And wherever I was, there was a child with me — and a child might answer my questions more readily than an adult" (20). Here, the black narrator knows what please him well: "I looked at him. He looked back, curious and unafraid. He was not Rufus. I could see that now. He had the same red hair and slight build, but he was taller, clearly three or four years older. Old enough, I thought, to know better than to play with fire. If he hadn't set fire to his draperies, I might still be at home" (20).

Maintaining this knowledge is very crucial for the self because "the term colonization is an alternative to the idea of personhood and to the concept of role. Within this perspective, identity and the self are discursively produced in the course of communication. Societal discourses make available a range of positions, that is, a set of categories that people identify with, as well as their meanings" (Davies \& Harré 35). Furthermore, "due to its 'here and- now' quality, positioning can be seen as a conceptualization of 'doing identities' in colonialism. This perspective is comparable with the social representations approach in that positions not only 'locate' people within social relations and discursive 'storylines', but also provide people with ways of making sense of the world" (35). This "position incorporates both a conceptual repertoire and a location for persons within the structure of rights and duties for those who use that repertoire. Once having taken up a particular position as one's own, a person inevitably sees the world from the vantage point of that position" (35)as well as "in terms of the particular images, metaphors, storylines and concepts which are made relevant within the particular discursive practice in which they are positioned" (Davies \&Harré 35).

Such kind of identity is evident in the whites' treatment of the blacks in Kindred: "The white man's red hair told me who he must be. His face was already too much of a mess to tell me" (117). The whites want to fight the blacks to colonize them: "He was losing his fight—had already lost it. The man he was fighting was his size with the same slender build, but in spite of the black man's slenderness, he looked wiry and strong. He had probably been conditioned by years of hard work. He didn't seem much affected when Rufus hit him, but he was killing Rufus" (117).

Thus, the relationship between the blacks and the whites is based on the struggle for identity. That is because "identity is conceptualised as a discursive construct and refers to the attribution of character, group membership and other meanings to an actor, while rights and duties refer to the moral order associated with this position" (Slocum-Bradley 25). Furthermore, this distinction "is useful for the elaboration of self-other relations and the consideration of power dynamics and norms in shaping those relations. (25). Identity distinction culminates in the "recognition or the absence of recognition" which "is a key issue in knowledge and identity construction because it defines the self-other relations involved in a context exposing the quality of self-other relations is crucial in understanding identity processes" (25). Hence, utilizing "the idea of rights and duties as associated with identity positions, we can stress the impact of power dynamics in our conceptualisation of identity. While the terms recognition and misrecognition define broadly the quality of self-other relations, rights and duties provide a more detailed view of the quality of the positions towards the 'other' embedded in these relations"' (25).

Identity recognition is exemplified in the use of war gadgets, like knives used to fight the colonizer in Kindred: "my knife [the narrator's knife]. I arrived on my knees because of the dizziness, but I was immediately alert and wary. I was in the woods either late in the day or early in the morning" (117). During the narrator's stealthy fight, he meets other black people, among them is a women, who also want to fight to reclaim their land: "The sun was low in the sky and surrounded as I was by trees, I had no reference point to tell me whether it was rising or setting. I could see a stream not far from me, running between tall trees. Off to my opposite side was a woman, black, young — just a girl, really — with her dress torn down the front. She was holding it together as she watched a black man and a white man fighting" (117).The self-other relationship is complicated because the whites practice hegemony over the blacks. The following section will discuss the conceptualization of this hegemony. 


\section{Hegemony}

Hegemony is a postcolonial concept indicating the practices use by powerful authorities to obtain sustained supremacy (Fine 19). It is "the dominant discourse surrounding the role of the state in the colonial tends to view state involvement in the colonialism as negative, 'power making' and to be avoided, except perhaps as a minimalist regulator. Although we can talk about a "post-colonial consensus", the orthodoxy of the term remains largely intact" (22)Indeed, the concept is used to tackle "the various international colonial institutions" which "have argued that colonized states lack the capacity to pursue developmental state policies, whilst being far too susceptible to vested interests in the political realm. Elites in colonial worlds have frequently taken onboard such vision and have come to believe, albeit at times reluctantly and at varying speed sacross the colonized territories, that a minimalist role for the colonizer is substantial" (22).

In Kindred, hegemony is evident in the whites' killing of the blacks: "then it occurred to me that he might really be doing just that - killing the only person who might be able to help me find Kevin. Killing my ancestor" (117). Here, the narrator refers to the killing of his ancestors: "what had happened here seemed obvious. The girl, her torn dress. If everything was as it seemed, Rufus had earned his beating and more. Maybe he had grown up to be even worse than I had feared. But no matter what he was, I needed him alive-for Kevin's sake and for my own" (117). Thus, it is colonialism which brings about hegemony.

By using hegemonic strategies, the whites provide "determined developmental elite; relative autonomy; a powerful, competent and insulated bureaucracy; a weak and subordinated civil society; the effective management of non-state economic interests; and legitimacy and performance" (Leftwich 405). Moreover, hegemony encompasses "the elaboration of colonial political policy and is informed by such considerations as power and vicious murders" (405). In this manner, the ruling "elite simply is passed off as an alliance of colonial forces. Rather, the powerful bloc represents a dialectical unity between the colonized and the colonizer, and between the original land owners and colonial masses" (405). It also manifest isthe connection between "the articulation of theory and practice - in this case, between the colonizer's developmental ideology and its implementation comes out. This colonial bloc seeks to 'affirm' and maintain the levers of colonial power in its quest to build a hegemonic project and reflects the necessary reciprocity between the colonized and the colonizer" (Gramsci 366).

In Kindred, this colonial elite is a result of the fight between the blacks and the whites: "I [the narrator] tried to see her [a black woman] again as the thin, frightened child I remembered - the child I had seen only two months before" (119). Therefore, the blacks could not be elite since they are colonized, the narrator describes the impossibility of becoming this elite: "It was impossible. But I should have been used to the impossible by now-just as I should have been used to white men preying on black women. I had Weylin as my example, after all. But somehow, I had hoped for better from Rufus. I wondered whether the girl was pregnant with Hagar already" (119).

Accordingly, hegemony is a colonial "relationship" which "is actualised via human, moral and political modes that transcend confined notions of colonial-corporate interests and instead reflect freer "ethico-political" ones. This ethicopolitical aspect serves to assist in building both economic configurations but also supplies a justifying and legitimising aspect" (Pempel 158). It is argued that colonial hegemony appears in "such a project" which reflects "broad and coherent thrusts or biases in the behaviour of national-states" (158). In this way, hegemony is "implicit in this notion of colonial regime in which the expectation that specific components of state and colonizer's power will be mutually reinforcing (though not necessarily without challenge) and that public actions will reflect this interaction" (158). More specifically, in the colonized world "the character of a regime is determined by the societal and colonial coalitional base on which a state rests, thepower of that stage...and the institutionalisation and bias of the public policies that result" (158).

These colonial and social dimensions are pertinent to Kindred. The narrator talks about the poor stat of the blacks after the advent of the whites colonizers "All in all, though, he probably looked worse off than he was. No doubt he had some bruises that I couldn't see without undressing him, but I didn't think he was badly hurt. He would be in some pain when he came to, but he had earned that" (121). He also tells his tiredness of the fight: "I sat on my knees, watching him, first wishing he would hurry and regain consciousness, then wanting him to stay unconscious so that Alice and her husband could get a good start. I looked at the stream, thinking that a little cold water might bring him around faster. But I stayed where I was. Isaac's life was at stake. If Rufus was vindictive enough, he could surely have the man killed. A slave had no rights, and certainly no excuse for striking a white man" (121).

The concept hegemony presents a desire to be dominant over other entities because "having a shared desire to consolidate their hold on the post-independent state means to accumulate and gain influence, and the elites that emerged at and after independence joined to form a nascent bloc" (Miliband 11). Furthermore, this independence is appropriated "as the construction of hegemony cannot be separated from the concept of a bloc, neither can the notions of reciprocity: the development plans advanced by the ruling party which have benefited a broad section of the country might be seen in this light" (11). This colonial reciprocal created a "virtuous circle" of support where there existed the usage of state machinery to reward supporters and at the same time generated further support, predicated on policies that broadly benefited the long-term interests of the nation's territory" (11). At the same time, hegemony is "remarked by the colonial construction which is reflected in the capacity of the ruling classes to persuade subordinate ones that, whatever they may think of the social order being built, there was no powerful alternative' to it" (11).

In Kindred, Luke exemplifies this covetous colonial encounter between the blacks and the whites: "Luke ... he would just go ahead and do what he wanted to no matter what Daddy said. Daddy always said he thought he was white. One 
day maybe two years after you left, Daddy got tired of it. New Orleans trader came through and Daddy said it would be better to sell Luke than to whip him until he ran away" (138).This experience makes the narrator laments his past which was empty of colonial supremacy over his black nation: "I closed my eyes remembering the big man, hearing again his advice to Nigel on how to defy the whites. It had caught up with him. "Do you think the trader took him all the way to New Orleans?" I asked. "Yeah. He was getting a load together to ship them down there." I shook my head. "Poor Luke. Are there cane fields in Louisiana now?" (138).

It is the colonial hegemony which creates such tense relationship. This is because "hegemony contained psychological aspects to it 'involving some kind of suppressed acceptance — not necessarily explicit—of the socio-political order or of certain vital aspects of that order"' (Femia37).This supremacy is 'the supremacy of a colonial group which manifests itself in two ways, as 'domination' and as 'intellectual and moral leadership'...A social group can, and indeed must already exercise 'leadership' before winning governmental power; this indeed is one of the principal conditions for the winning of such power"(Molutsi126). Such hegemony "has in fact asserted a superior colonial policy which benefit from the colonized; and it has an influential effect on the colonized society; whereby a colonial state is not an instrument of suppressive authority" (126). Instead, it is capable "because of its relative autonomy from the major classes in society of concurrently advancing accumulation colonization in favour of the suppressed classes on the one hand and welfare programmes for the colonial masses on the other. The latter especially is important if the authority is to establish itself as legitimate for the entire colonial period" (126).

This authority is prevalent in Kindred. It is the reference to the colonial history of the whites: "You're reading history, Rufe. Turn a few pages and you'll find a white man named J. D. B. DeBow claiming that slavery is good because, among other things, it gives poor whites someone to look down on. That's history. It happened whether it offends you or not. Quite a bit of it offends me, but there's nothing I can do about it" (140).In fact, it is the history of the colonial whites: "And there was other history that he must not read. Too much of it hadn't happened yet. Sojourner Truth, for instance, was still a slave. If someone bought her from her New York owners and brought her South before the Northern laws could free her, she might spend the rest of her life picking cotton" (140). Such colonial hegemony will be explained in terms of ambivalence studied in the following section.

\section{Ambivalence}

In The Location of Culture (1994), Bhabha claims that ambivalence is a "subject of a difference that is almost the same, but not quite" (122). Additionally, the concept is important since it describes "the unstable environment that the colonized is forced to either adapt to or work really hard to reject. The colonial power is strong and the possibility to become a member in a hybrid community is more or less inevitable" (122). Furthermore, Bhabha discusses the notion of ambivalence in Nation and Narration (1990). He argues that ambivalence appears "when the two cultures mix and whether or not they adapt to this hybrid environment, and "Hybridity is the perplexity of the living as it interrupts the representation of the fullness of life" (314). Here, hybridity is tackled as a main product of ambivalence.

In Kindred, for example, the narrator becomes adapted to the whites though they are his enemies:"I hid from three white men who rode by on horseback. They had a dog with them, and I was afraid it would smell me and give me away" (172). The narrator's adaptation to the whites is a result of his appreciation of their powers. That is why he is no longer afraid of them: "Luckily, the wind was in my favor, and it went on its way. Another dog found me later, though. It came racing toward me through a field and over a rail fence, barking and growling. I turned to meet it almost without thinking, and clubbed it down as it lunged at me" (172).

The concept of ambivalence "includes non-state or even anti-state factors. Although less acknowledged, the resistant politics of revolutionary movements have contributed their fair share to the wider militarization of these societies (as elsewhere)" and "the countering of statist militarism with forms of revolutionary resistance that tend to become indistinguishable from the former raises pressing but unanswered questions to do with colonial ethics" (Roy 135). Consequently, "these concerns are arguably more complex when we turn to the politics of resistant colonial violence, usually justified as a response to the violence of the state, and for the sake of democratic ends" (135). In fact, the colonial resistance disappears in a way "in which violence is located has not only precluded, in many instances, its outright condemnation but has also prevented a serious consideration of its underlying ethical presuppositions and ambiguities" (135).

To connect this to Kindred, the colonial resistance disappears when the narrator adapts to the presence of the whites: "I looked around. There was a white man, gray-bearded and dusty, riding around the side of the main house toward us. I thought at first that it was the Methodist minister. He was a friend and sometime dinner guest of Tom Weylin in spite of Weylin's indifference to religion" (183). He also does not see any black child around; and he gradually adapts to the whites' religion: "But no children gathered around this man as he rode. The kids always mobbed the minister-and his wife too when he brought her along. The couple dispensed candy and 'safe' Bible verses ('Servants, be obedient to them that are your masters ...'). The ambivalent relationship culminates in the colonial encounter between the blacks and whites. This encounter ends with the adaptation to each other. Even children become happy with the whites' gifts: "The kids got candy for repeating the verses. I saw two little girls staring at the gray-bearded stranger, but no one approached him or spoke to him. He rode straight back to us, stopped, sat looking at both of us uncertainly" (183).

This is the ambivalent relationship which sets "the roots of heterogeneous contexts and formats, denying them the power to completely define one's identity, translating ideas, transcoding images, transplanting behaviours, exchanging rather than imposing" (Bourriaud 22). It is the reconcialtion of opposites which uses "these forms to elicit different 
narratives that translate their experiences (106). It decodes "the complexities, ambiguities and ambivalences of subjectivity, identity, culture and territory in the globalised context, and the ways they specifically address the experiences of diaspora, immigration, exile, transnationality and re/dislocation. Their creative critiques often operate through subtle and evocative methods that contrast with the oppositional modes of earlier colonial practices" (106).

The ambivalent relationship between the blacks and the whites, in the long run, affirms that the blacks perceive the whites as covetous and suppressive colonizers, but they are envied for their power. On the other hand, the whites perceive the blacks as backwarded, but envied for their lands. In Kindred, such conceptualization embodies the narrator and Kevin gradually developed relationship with the whites, especially Rufus:

For one thing, Kevin and I had lived here together for only two days. The fact that I'd had eight extra days here alone didn't really help. The time, the year, was right, but the house just wasn't familiar enough. I felt as though I were losing my place here in my own time. Rufus's time was a sharper, stronger reality. The work was harder, the smells and tastes were stronger, the danger was greater, the pain was worse ... Rufus's time demanded things of me that had never been demanded before, and it could easily kill me if I did not meet its demands. That was a stark, powerful reality that the gentle conveniences and luxuries of this house, of now, could not touch (italics in original)' (191).

\section{Conclusion}

This chapter has studied Butler's Kindred. The main focus has been on the colonial powers in the novel. These powers involve the racial encounters between the blacks and the whites. Both powers have a different conceptualization and perception of each other. Therefore, the study emphasizes the racial side of the colonial relationship between the blacks and the whites. In the main, the colonial relationships are characterized by a tense and severe clash or conflict which results in a distorted human harmonious life. The essence of such conflict brings about destruction and harmful practices in the colonial world of the blacks and the whites simultaneously. Accordingly, the study has focused on the way in which the blacks and the whites struggle to affirm their identities. The blacks strive for confirming their black or authentic identity regardless of the whites' covetous practices which subjugate the blacks to their domination and hegemony. The whites, on the other hand, try to maintain their original identity by emphasizing their cultural hegemony on the blacks. This struggle results in a colonial encounter which makes new identities. That is the blacks refuse to adopt or accept the colonial whites. As a result, the whites use their colonial superiority to force the blacks to accept their culture.

The analysis of this relationship highlights three concepts to identify and analyze such colonialism. First, Said's concept of self-other relationship has been applied to discover the blacks' struggle to affirm their original identity. They maintain their cultural traditions and customs to fight the colonial whites on the basis of their contempt with their traditional human roots which make them equal to the whites. The whites try to suppress this struggle and impose their culture on the blacks. Second, the concept of hegemony is applied to investigate the cultural practices used by the whites to thwart the blacks from maintaining their African identity. Third, Bhabha's concept of ambivalence has been used to argue how the blacks judge the whites and vice versa.

\section{References}

Bhabha, H.K. (1990). Nation and Narration. London: Routledge

---. (1994). The Location of Culture. London: Routledge.

Bourriaud, N. (2009). The Radicant. New York: Lukas \& Sternberg.

Butler, O. (2003). E. Kindred. Boston: Beacon Press.

Davies, B. \& Harré, R. P. (1999). The Discursive Production of Selves in R. Harré \& L. van Langehove (Eds.), Positioning Theory. Oxford: Blackwell

Duveen, G. (1993). “The development of social representations of gender”. Papers on Social Representations, 2(3),171177.

Femia, J. (1981). Gramsci's Political Thought: Hegemony, Consciousness and the Revolutionary Process. New York: Oxford University Press

Fine, B. (1999). The Developmental State is Dead_Long Live Social Capital?, Development and Change. 30.1

Gramsci, A. (1971). Selections From the Prison Notebooks. London: Lawrence and Wishart

Jubouri Al_Ogaili, T. A. \& Babaee, R. (2015). Mutinous Colonialism: Navigating Self-Other Dichotomy in Octavia Butler's Survivor. Advances in Language and Literary Studies, 6(4),166-170

Leftwich, A. (1995).'Bringing Politics Back In: Towards a Model of the Developmental State". Journal of Development Studies. 31.3

Loomba, A. (2015). Colonialism-Postcolonialism. London: Routledge

Marková, I. (2003). Dialogicality and Social Representations: The Dynamics of Mind. Cambridge: Cambridge University Press

Miliband, R. (1994). Socialism for a Sceptical Age.London: Verso 
Molutsi, P. (1989). Whose Interests Do Botswana's Politicians Represent? in J. Holm and P. Molutsi, eds, Democracy in Botswana. Gaborone: Macmillan

Moscovici, S.The History and Actuality of Social Representations. In G. Duveen (Ed.), Social Representations: Explorations in Social Psychology. New York: New York University Press, 2000.

Pempel, T.J. (1999). The Developmental Regime in a Changing World Economy in M.Woo-Cumings, eds, The Developmental State. Ithaca, NY: Cornell University Press

Psaltis, C. (2005). Communication and the Construction of Knowledge or Transmission of Belief: The Role of Conversation Type, Bahavioral Style and Social Recognition. Studies in Communication Sciences, 5(2), 209-228

Roy, S. (2009). The Ethical Ambivalence of Resistant Violence: Notes from Postcolonial South Asia. Feminist Review, 9(1), 135-53.

Said, E. W. (1979). Orientalism. New York: Vintage Books

Slocum-Bradley, N. (2009). The Positioning Diamond: A Trans-Disciplinary Framework for Discourse Analysis. Journal for the Theory of Social Behaviour. 40:1-29. 